\title{
Relationships between Structure, Composition, and Dynamics of the Pristine Northern Boreal Forest and Air Temperature, Precipitation, and Soil Texture in Quebec (Canada)
}

\author{
Louis Duchesne and Rock Ouimet \\ Direction de la Recherche Forestière, Forêt Québec, Ministère des Ressources Naturelles et de la Faune du Québec,
} 2700 Einstein Street, QC, Canada G1P 3W8

Correspondence should be addressed to Louis Duchesne, louis.duchesne@mrnf.gouv.qc.ca

Received 12 September 2008; Revised 26 November 2008; Accepted 4 December 2008

Recommended by Han Chen

This study reports on the contemporary structure, composition, and dynamics of the pristine northern boreal forest in Quebec, Canada, associated with air temperature, precipitation, and soil texture, using 147 permanent sample plots located at the limit of continuous forest in Quebec. The results show that tree species composition of stands is associated with stand age, soil texture, air temperature, and precipitation regime. After establishment of the pioneer cohort, the postsuccessional stand dynamics differed among temperature and precipitation regimes, probably because of their influence on tree growth. Our results support the hypothesis that shifts in forest composition related to stand dynamics and the subsequent senescing phase associated with the old growth stage generally occur sooner and proceed faster on more fertile sites due to quicker growth and the subsequent earlier mortality of pioneer species. This study suggests that climate warming should accelerate the successional dynamics of these ecosystems through its positive influence on tree growth.

Copyright (C) 2009 L. Duchesne and R. Ouimet. This is an open access article distributed under the Creative Commons Attribution License, which permits unrestricted use, distribution, and reproduction in any medium, provided the original work is properly cited.

\section{Introduction}

The circumboreal forest is the most extensive terrestrial biome in the world, encompassing some 14 million $\mathrm{km}^{2}$, or $32 \%$ of the earth's forest cover, and constituting one of the largest reserves of untapped wood fibre [1]. At the global level, the boreal forest is subjected to temperature and precipitation gradients that largely control the range of major tree species and the distribution of the main boreal zone [2]. While the causal chains between tree growth dynamics and the simple climatic variables are somewhat lengthy and involved, two of these climatic variables, air temperature and precipitation, explain more than $60 \%$ of some dominant species' growth variation, as measured by tree ring chronology [3]. Tree growth and forest dynamics are also affected by factors other than climate, such as soil water and nutrient availability. A previous study has shown the possibility of deriving site quality indices from biophysical variables to model tree growth and yield for the main boreal forest tree species [4].

Forest fire is recognized as the main disturbance agent in the boreal coniferous forest, and as being of great importance for plant succession, ecosystem processes, landscape structure, and biological diversity [5]. The frequency, size, intensity, seasonality, and type of fire depend on air temperature, precipitation, and soil characteristics, in addition to forest structure and composition [6]. The American boreal forest is characterized by relatively short fire cycle periods and by a mosaic that is mainly composed of postfire even-aged stands [7]. However, long fire intervals that allow changes in canopy dominance and the development of uneven-aged forests have also been reported, particularly in the eastern boreal forest [8-10]. Also, it has been demonstrated that the postfire dynamics of the black spruce forest of the clay belt 
region in Quebec and Ontario differ among soil substrates [11-13].

Currently, there are no reported large-scale field observations documenting the combined effect of precipitation and temperature regimes, along with soil characteristics, on the dynamics of the northern boreal coniferous forest. In a changing environment, it is generally recognizedin addition to modeling efforts - that adequate monitoring protocols are needed to establish rates of change in environmental drivers and in species and community responses to those changes $[6,14]$. Detailed studies are needed in a variety of environments to detect recurrent patterns and underlying processes, and to improve our comprehension of the interactions among climate, disturbances, and successional trajectories [6]. The objective of this study was to analyze the relationship between air temperature and precipitation regimes, along with soil texture, and the contemporary structure, composition, and dynamics of the pristine northern coniferous boreal forest in Quebec, Canada. We wanted to test the hypothesis that the dynamics of the continuous northern boreal forest differed among air temperature and precipitation regimes, along with soil characteristics. We hypothesized that tree growth was greater, and that the successional dynamics of the northern boreal forest are faster on warmer, wetter and more fertile sites. This analysis should provide a better comprehension of the possible effect of climate and soil characteristics on the contemporary northern boreal forest. Such information is a prerequisite for adequate conceptualization and framing of forest growth and yield models used in forest management planning.

\section{Material and Methods}

Since 1970, approximately 12300 permanent sample plots have been progressively established and periodically inventoried in the continuous forest range of Quebec by the provincial Ministry of Natural Resources and Wildlife to improve the knowledge base of provincial forest resources, notably forest dynamics. Among them, 7155 plots were established during the first decade following the initiation of surveys (1970-1977). By 2005, approximately 300 plots located above latitude $50^{\circ} \mathrm{N}$ had been measured four times, with a time interval between successive surveys ranging from 4 to 11 years. These plots were distributed a few kilometres above and below the current northern limit of the forest management area in Quebec $\left(50\right.$ to $52^{\circ} \mathrm{N}$ and -68 to $\left.-78^{\circ} \mathrm{W}\right)$, mainly within the black spruce-moss bioclimatic domain [2]. Along this transect, maximum elevation and precipitation increase from west to east from 125 to $800 \mathrm{~m}$, and from 700 to $1100 \mathrm{~mm} \mathrm{yr}^{-1}$, respectively, while mean annual temperature decreases from 4.5 to $0^{\circ} \mathrm{C}$ [15]. The fire cycle differs considerably among regions and the time period considered. Cycles of less than 100 years to more than 500 years have been reported [16]. Most of the area is dominated by Picea mariana, which tends to form monospecific stands. These plots represent the pristine northern boreal forest in Quebec, given that forest operations have not yet reached these latitudes.
2.1. Dendrometric and Site Data. Permanent sample plots were circular, covering $400 \mathrm{~m}^{2}$ (radius $=11.28 \mathrm{~m}$ ). At the time of establishment and successive measurements, every tree having a diameter at breast height (DBH; $1.3 \mathrm{~m}$ above the highest root) larger than $90 \mathrm{~mm}$ was numbered with paint, classified according to its species and condition (recruit, alive, standing dead, fallen, or harvested), and its DBH was measured using a diameter tape to the nearest millimetre. Nine dominant trees were also sampled systematically nearby each plot with an increment borer at breast height (at the first sampling) for tree age approximation based on tree ring count. Their height was also measured using a clinometer or a hypsometer. Main soil characteristics (forest floor thickness, depth of the B horizons, drainage class) were recorded, and mineral $\mathrm{B}$ horizons were sampled for particle size composition (sand, silt, and clay content), following the Bouyoucos method [17]. Visual indications of perturbation (insect defoliation, windfall, fire, or cutting) were recorded when more than $25 \%$ of the stand basal area were affected. Spruce budworm defoliation was recorded in only one plot during the first period. Partial windfall was recorded in three plots and seven plots during the first and the second period, respectively, while a partial burn was observed in only two and three plots during those periods.

2.2. Meteorological Data. Daily air temperature and precipitation from 1977 to 2001 were computed for each permanent plot using BioSIM, a system designed to model insect development at the landscape level on the basis of daily weather time series [18], and subsequently used for biophysical site index development [4]. This system performs two main functions: (1) matching georeferenced sources of weather data to the specified locations, and (2) adjusting data from the selected stations for differences in latitude, longitude, elevation, slope, and aspect between the source of weather data and a specified location. Data were available from 378 normal-generating weather stations scattered throughout Quebec, but mainly distributed in the southern part of the province. Data from 42 weather stations located in the northern part of the province were used to generate seasonal climatic conditions at the studied plots (see Figure 1).

2.3. Data Handling and Statistical Analysis. Each record of the permanent plot dataset was compared with previous and successive evaluations, and logical consistency was used to check and correct the data, if necessary, according to the validation procedure outlined in Duchesne and Ouimet [19]. We selected all plots that were forested at the time of the first survey and for which information on vegetation, stand age, and soil texture was available (organic soils were not considered). The final database contained 147 plots with over 6800 trees for the purpose of this study (see Figure 1).

For each plot, parameters reflecting initial stand structure and composition were computed, including basal area proportion of individual species, dominant stand height, total basal area, and total number of stems. The Gini coefficient (GC) describing stand diameter diversity was 
also computed [20]. GC was found superior with respect to discriminating ability and capability of providing logical ranking of different distributions [20]. Parameters reflecting contemporary dynamics of the stands (growth, mortality, and recruitment) were computed in terms of basal area $\left(\mathrm{dm}^{2} \mathrm{ha}^{-1} \mathrm{yr}^{-1}\right)$ for two distinct periods corresponding to the first two (1970-1975 and 1978-1980) and the last two measurements (1990-1992 and 1998-2001). For a given period, mortality and net recruitment were evaluated by dividing the total basal area of dead or new stems by the time between surveys and the total plot area sampled, respectively. Growth of living trees was also assessed in terms of basal area. Finally, net growth (growth of living trees + net recruitment - mortality) was estimated by the difference in the total basal area of living trees between successive surveys divided by the time interval between them and the total sampled plot area [19].

Stand age was estimated by averaging the ring count of sampled trees. Stand age was categorized into three classes containing a more or less equivalent number of plots; the upper limit of the first and the second classes being the 33.3\% and the $66.6 \%$ percentile, respectively. Stand age varied from 22 to 59 years, 60 to 100 years, and 101 to 200 years for the first, second, and third classes, respectively. We could not ensure that the cored trees in the last age class belonged to the postfire cohort. We could, however, ensure that no major stand clearing occurred since the recruitment of these trees.

For each plot, normal mean annual temperature and total annual precipitation were computed over the 19772001 period. Mean seasonal (winter: Jan., Feb., Mar.; spring: Apr., May, Jun.; summer: Jul., Aug., Sept.; autumn: Oct., Nov., Dec.) temperature and total precipitation were also computed over the two distinct periods studied. Soil surface area (SSA) was estimated using the following equation [21]:

$$
\begin{aligned}
\text { SSA }= & (0.003 \times \text { Sand }+0.022 \times \text { Silt }+0.08 \times \text { Clay }) \\
& \times \text { Dens } \times 10^{6},
\end{aligned}
$$

where SSA is the soil specific surface area $\left(\mathrm{m}^{2} \mathrm{~m}^{-3}\right)$, Sand, Silt, and Clay variables are particle fractions (\%), and Dens is mineral soil density $\left(\mathrm{g} \mathrm{cm}^{-3}\right)$. Data for soil density were not available. Consequently, a mineral soil density of $1 \mathrm{~g} \mathrm{~cm}^{-3}$ was used for all plots. Soil surface area was chosen as the soil parameter because it reflects both soil waterholding capacity and soil nutrient availability, which in part determine site productivity [22]. Temperature, precipitation, and SSA were categorized into two classes each (cold and warm sites; wet and dry sites; fine and coarse textured soils (from SSA)) containing approximately the same number of stands (see Table 1). Cut level classes were not based on biological considerations. They were set to ensure that each class contained approximately the same number of plots. Temperature, precipitation, SSA, and age classes result in 24 categories $(2 \times 2 \times 2 \times 3)$, each containing 6 to 7 plots. The relationship between stand age, air temperature, precipitation, soil texture and initial stand characteristics, and stand dynamics parameters (growth, mortality, and recruitment) in both periods were examined with analyses of variance using the mixed model procedure (PROC MIXED)

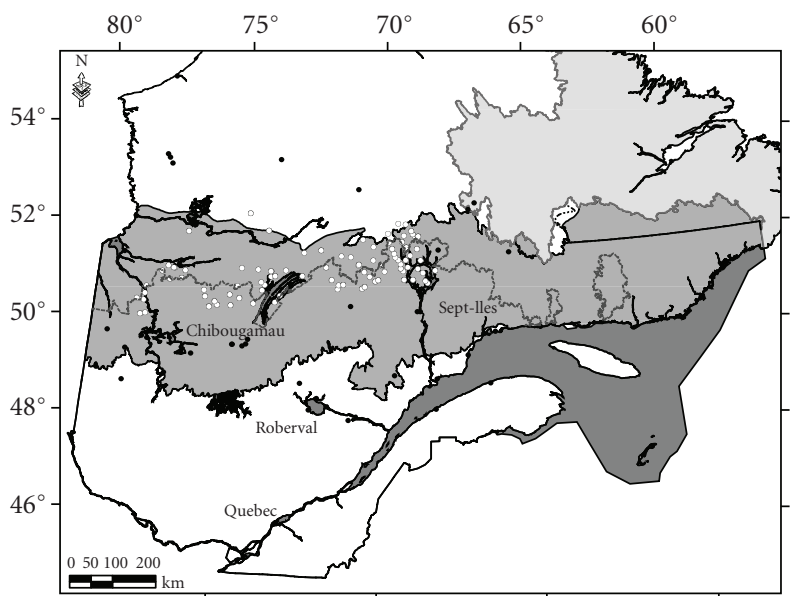

FIGURE 1: Location of the 147 forest permanent sample plots (white circles) located above the 50th parallel, and meteorological stations (black circles) used to generate climatic conditions at each plot. Note that several plot locations are superimposed due to the map scale. The shaded area corresponds to the black spruce-moss bioclimatic domain, while the grey hatched line corresponds to the limit of the current managed forest area in Quebec, Canada.

in SAS [23]. Linear and second-degree polynomial contrasts were built to assess the effect of stand age, temperature, precipitation, and soil texture on every dependent variable. Calculations of the linear and quadratic coefficients for unequally spaced time intervals were made according to Robson [24]. The chronosequence approach, in which stands of differing ages are compared to provide insight into changes that occur over time, is a commonly used technique [12,25]. As a "substitute of space for time," the proper use of a chronosequence requires that differences among plots in terms of edaphic, meteorological, and disturbance history must be kept to a minimum. Our approach differed from the commonly used technique for which stands were generally a priori categorized based on site characteristics (e.g., soil type, site index productivity) in order to form a chronosequence. In the approach we followed, the relationships between stand characteristics or stand dynamics parameters and stand age, air temperature, precipitation, and soil texture were statistically tested.

Comparison of the results obtained from the analysis of initial stand characteristics and from the contemporary stand dynamics parameters should provide insights on the change in forest dynamics occurring over the mid term (last 100 years), while a comparison of results of the contemporary dynamics between the two measurement periods should provide insights into changes in forest dynamics over the short term (last 30 years). In order to assess differences in climate conditions over the two periods studied, mean seasonal temperature and precipitation were compared with a Wilcoxon signed-rank test [26].

\section{Results}

3.1. Stand Age, Temperature, Precipitation, and Soil Texture Class Distribution. Stand age and soil texture classes were 
TABLE 1: Mean, standard error and number of plots included in air temperature, precipitation, and soil texture classes.

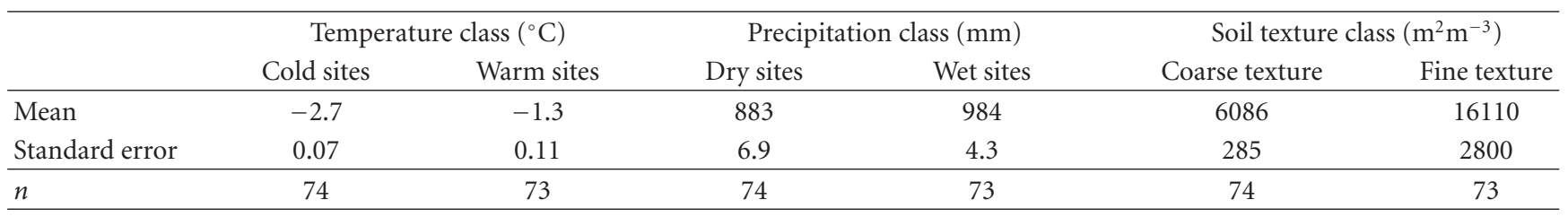

distributed throughout the study area with no specific regional pattern (see Figure 2). Conversely, temperature and precipitation regimes showed distinct patterns over the territory. Indeed, most plots in the western part of the territory were among the warmer temperature and the lower precipitation classes, while most plots from the eastern sector exhibited a lower temperature and a higher precipitation regime. Some plots were exceptions within those regions.

3.2. Stand Composition. There was a significant quadratic increasing trend in the proportion of $P$. mariana with stand age class $(P=.025$; see Figure 3$)$. On average, $P$. mariana represented $45.8 \%$ of stand basal area of stands in the 40 year age class, while the proportion reached $88.2 \%$ for the 120 -year age class. On average, the proportion of $P$. mariana was $9.6 \%$ greater on fine textured soils as compared to coarse textured soils, but the difference was only marginally significant (see Figure 3; $P=.054$ ). The proportion of Abies balsamea also increased with stand age, but the relation was linear $(P=.010)$. On average, $A$. balsamea proportions increased from $1.6 \%$ to $9.0 \%$ when the stand age class passed from 40 to 120 years, respectively (see Figure 3 ). There was no difference in the proportion of this species among soil texture classes $(P=.754)$. The proportion of $A$. balsamea was greater on sites receiving more precipitation (average $9.6 \%$ ) and sites subjected to colder temperatures (average 10.6\%) than on drier (average 3.6\%) and warmer sites (average $2.6 \%)$, respectively $(P \leq .011)$. However, no significant interactions between temperature and precipitation regimes were detected. Contrary to $P$. mariana and A. balsamea, the proportion of Pinus banksiana decreased in a quadratic fashion as stand age class increased $(P \leq .001)$. On average, $P$. banksiana represented $46.1 \%$ of stand basal area in stands in the 40 -year age class, while this proportion dropped to $0.5 \%$ for stands in the 120 -year age class. A significant interaction with soil texture and precipitation regime was detected $(P=.028)$. On coarse-textured soils, proportions of $P$. banksiana were greater on sites receiving lower amounts of precipitation (mean proportion 30.9\%) as compared to sites receiving higher amounts (mean proportion 10.6\%); however, this difference was not perceptible on fine-textured soils (see Figure 3). Contrary to other species, the proportion of Betula papyrifera did not vary significantly with stand age. The proportion of this species was, however, associated with the precipitation regime $(P=.019)$, and this relationship differed slightly between the two soil texture classes (see Figure 3; $P=.054$ ). On coarse-textured soils, the proportion of $B$. papyrifera was estimated at $0.7 \%$ for sites receiving less precipitation, as compared to $11.0 \%$ for stands receiving higher amounts. On average, fine-textured soils had a lower proportion of $B$. papyrifera than did coarse-textured soils, but the effect of the precipitation regime was not perceptible on the fine-textured soils.

3.3. Stand Structure. Stand basal area, density, height, and GC increased with stand age class $(P \leq .001)$. The relationships were linear, with the exception of GC, which exhibited a quadratic trend. On average, stand basal area, density, and height were greater on warmer sites $\left(15.1 \mathrm{~m}^{2} \mathrm{ha}^{-1}, 961\right.$ stems ha $\left.{ }^{-1}, 14.8 \mathrm{~m}\right)$ than on colder sites $\left(10.3 \mathrm{~m}^{2} \mathrm{ha}^{-1}, 578\right.$ stems ha ${ }^{-1}, 13.6 \mathrm{~m}$ ) (see Figure $4 ; P \leq .002$ ). The trend of increasing basal area and density with stand age class also differed slightly between precipitation regimes $(P \leq .056)$. On sites receiving higher levels of precipitation, basal area and density increased from the first to the second age class, and then decreased for the 120-year age class. In contrast, on sites receiving less precipitation, basal area increased linearly with stand age class. Finally, stands in the warmer temperature class were less structurally diversified than those in the colder temperature class, as expressed by the lower values of GC for the warmer sites $(P=.005)$.

3.4. Stand Dynamics. Growth of living trees, recruitment, and net growth decreased as mortality increased linearly with stand age class (see Figure $5, P \leq .0004$ ). Trends were linear, with the exception of recruitment, which exhibited a quadratic trend. On average, growth of living trees was greater on warmer $\left(11.1 \mathrm{dm}^{2} \mathrm{ha}^{-1} \mathrm{yr}^{-1}\right)$ than on colder sites $\left(8.0 \mathrm{dm}^{2} \mathrm{ha}^{-1} \mathrm{yr}^{-1}\right)(P=.003$; see Figure 5$)$. Growth of living trees was also greater on sites receiving higher precipitation $\left(11.2 \mathrm{dm}^{2} \mathrm{ha}^{-1} \mathrm{yr}^{-1}\right)$ than on drier sites $\left(8.0 \mathrm{dm}^{2} \mathrm{ha}^{-1} \mathrm{yr}^{-1}\right)$ $(P=.005)$. Recruitment was also greater on sites receiving higher amounts of precipitation $\left(7.8 \mathrm{dm}^{2} \mathrm{ha}^{-1} \mathrm{yr}^{-1}\right)$ than on sites receiving lower amounts $\left(5.9 \mathrm{dm}^{2} \mathrm{ha}^{-1} \mathrm{yr}^{-1}\right)(P=$ .013). A significant interaction was detected with temperature, precipitation, and age class for recruitment $(P=$ .005). On sites receiving lower precipitation, recruitment was more or less stable over the various age classes. In contrast, on sites receiving greater precipitation, warmer sites exhibited a sharp decrease from the $40-\left(16.0 \mathrm{dm}^{2} \mathrm{ha}^{-1} \mathrm{yr}^{-1}\right)$ to the $80-\left(4.0 \mathrm{dm}^{2} \mathrm{ha}^{-1} \mathrm{yr}^{-1}\right)$ year age class, while on colder sites recruitment was roughly stable for the first two age classes, and decreased at the 120-year age class $\left(5.4 \mathrm{dm}^{2} \mathrm{ha}^{-1} \mathrm{yr}^{-1}\right)$. On average, mortality was also higher on warmer sites $\left(23.5 \mathrm{dm}^{2} \mathrm{ha}^{-1} \mathrm{yr}^{-1}\right)$ than on colder sites $\left(16.4 \mathrm{dm}^{2} \mathrm{ha}^{-1} \mathrm{yr}^{-1}\right)(P=.027$; see Figure 6$)$, but there was no interaction with stand age class. Net growth generally 


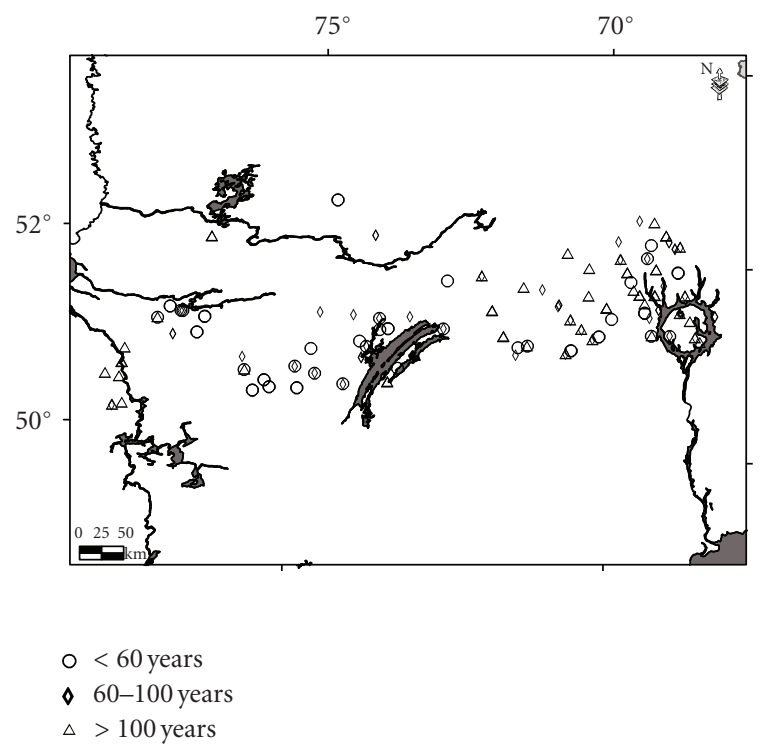

(a) Age class

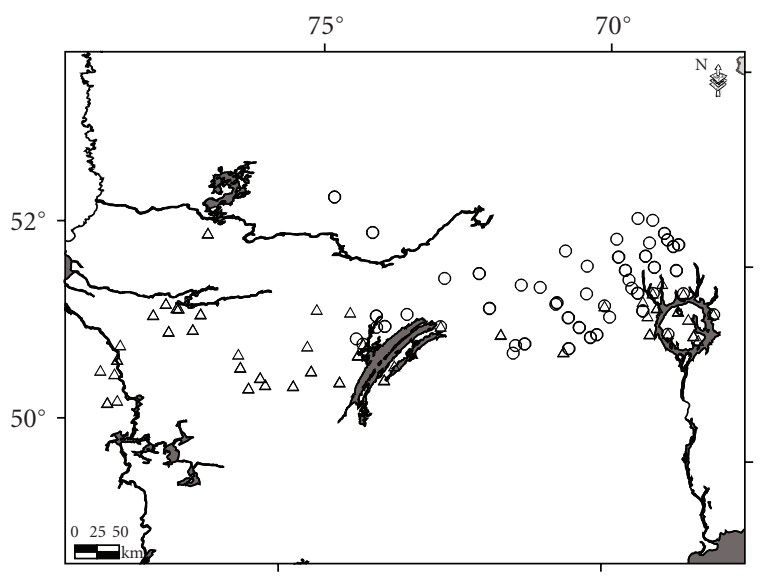

○ Cold sites

$\triangle$ Warm sites

(c) Temperature class

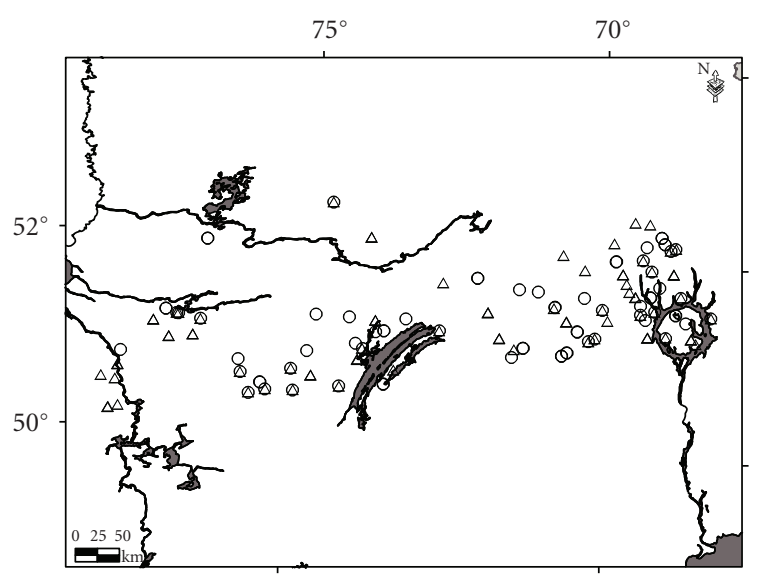

○ Coarse texture

$\Delta$ Fine texture

(b) Soil texture class

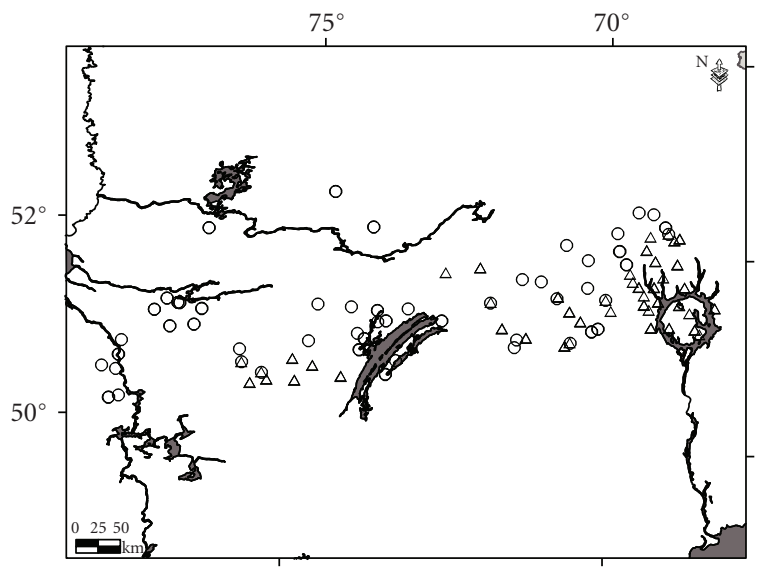

○ Dry sites

$\Delta$ Wet sites

(d) Precipition class

FIgURE 2: Distribution of stand age, soil texture, temperature, and precipitation classes throughout the study area.

declined with stand age, but trends differed both between temperature regimes and soil texture classes $(P \leq .029)$. These negative trends observed with increasing stand age class were more pronounced on warmer than on colder sites, and on fine-textured than on coarse-textured soils.

The only differences observed between the two periods (1970-1975 to 1978-1980 and 1990-1992 to 1998-2001) were the following: growth of living trees and stand net recruitment increased by $68 \%$ and $40 \%$ from the first to the second period studied, respectively $(P \leq .003$; see Figure 6), regardless of stand age, temperature, precipitation, or soil texture classes; mortality was also higher during the second period $\left(22.8 \mathrm{dm}^{2} \mathrm{ha}^{-1} \mathrm{yr}^{-1}\right)$ than the first one $\left(17.0 \mathrm{dm}^{2} \mathrm{ha}^{-1} \mathrm{yr}^{-1}\right)$, but the difference was marginally significant $(P=.073)$. Consequently, net growth of the studied stands was on average negative $\left(-3.4 \pm 2.3 \mathrm{dm}^{2} \mathrm{ha}^{-1} \mathrm{y}^{-1}\right)$, with no significant differences between the first and the second periods $(P=.681)$.

3.5. Climate Variations. Mean seasonal temperature and total precipitation for the two periods studied are shown in Table 2. On average, mean temperatures in summer and autumn were higher during the second period as compared to the first period studied $(P \leq .001)$. Marginally significant differences were also observed in spring temperatures, which were higher by $0.3^{\circ} \mathrm{C}$ during the second period as compared to the first period $(P=.052)$. The difference was more pronounced in autumn, during which temperature was $1.3^{\circ} \mathrm{C}$ higher during the second period as compared to the first. Concurrently, total winter and spring precipitation was $11.1 \%$ and $12.2 \%$ lower, respectively, while summer and autumn precipitation was $9.5 \%$ and $3.2 \%$ higher 


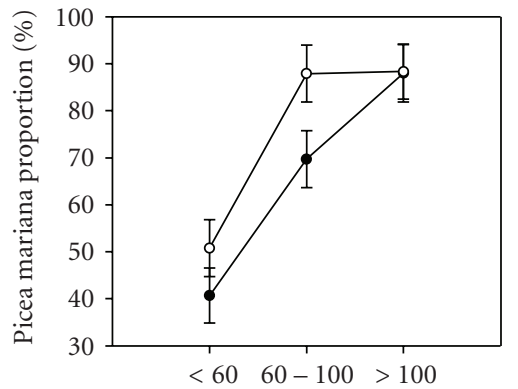

Stand age classes (years)

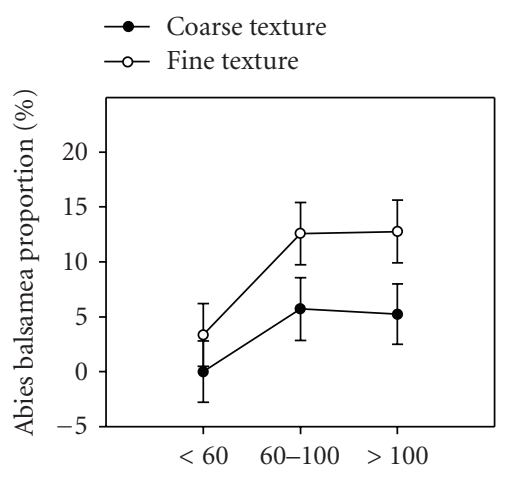

Stand age classes (years)
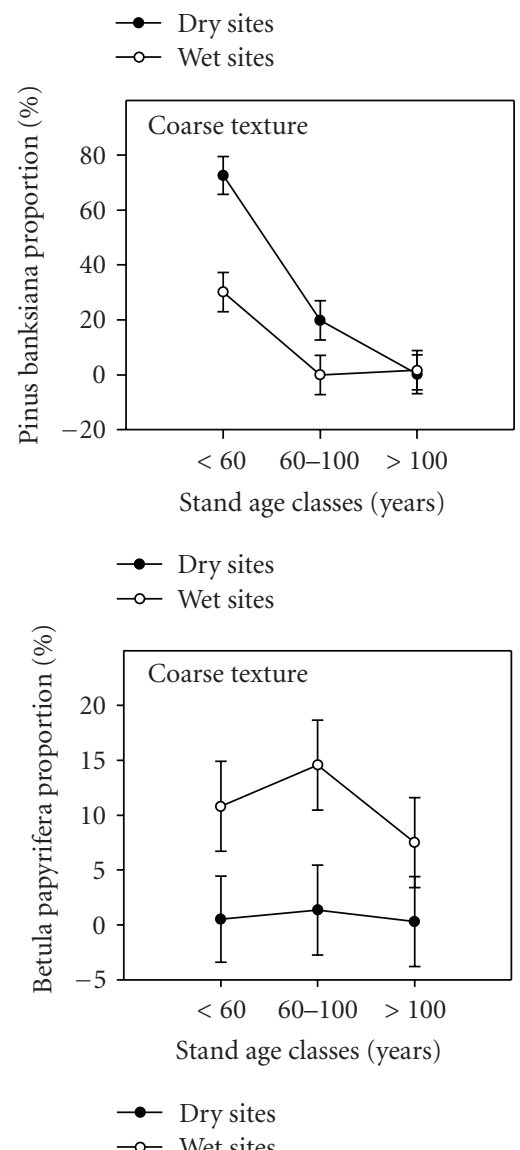

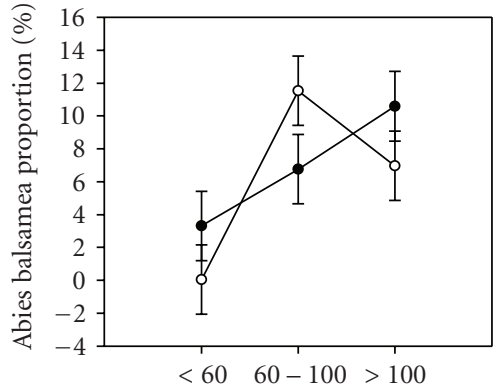

Stand age classes (years)

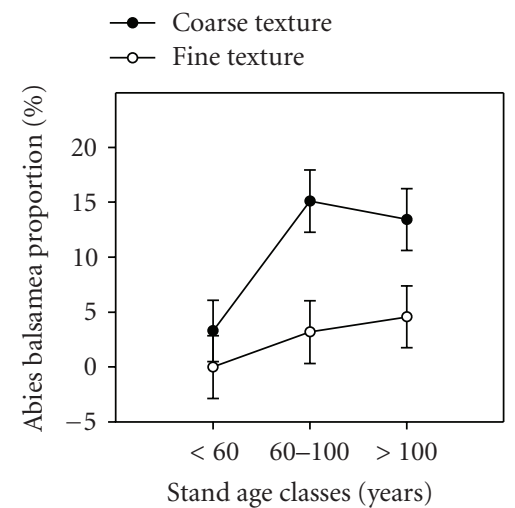

$\rightarrow$ Cold sites

$\multimap$ Warm sites

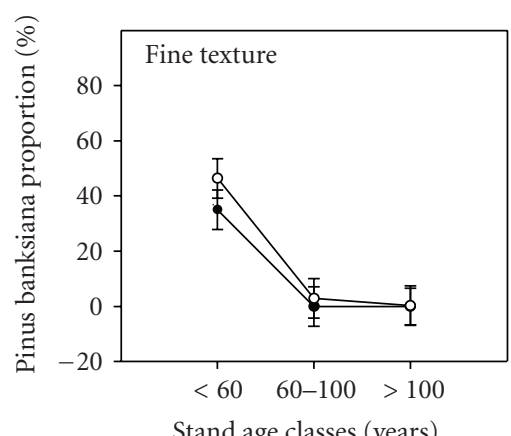

Stand age classes (years)

$\rightarrow$ Dry sites

$\multimap$ Wet sites

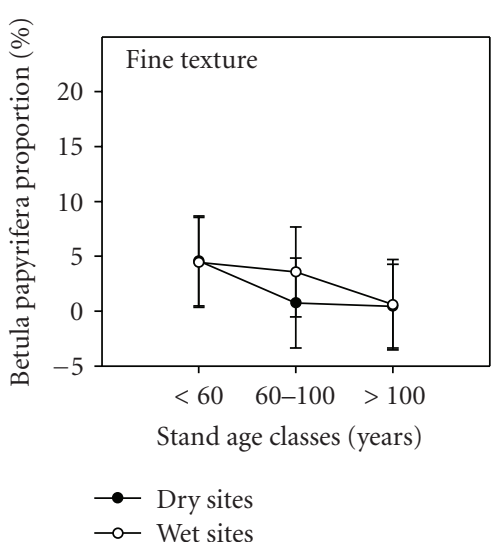

FIgURE 3: Relationships between stand composition and stand age, air temperature, precipitation, and soil texture. Data from the first inventory (1970-1975). 
during the second period, respectively, as compared to the first. Snow precipitation was also lower during the second period.

\section{Discussion}

4.1. Stand Composition. In the northern boreal forest, postfire forest composition is characterized by even-aged pure or mixed stands dominated by pioneer species. At maturity, this first cohort of trees is replaced by a second one dominated by shade-tolerant conifers [8]. In old-growth stands, the dynamics driven by gaps or insect epidemics permit the self-maintenance of heterogeneous uneven-aged stands of conifers [27]. In the present study, P. mariana and A. balsamea represented on average $88.2 \%$ and $9.0 \%$ of total basal area in older stands, respectively, while they represented only $45.8 \%$ and $1.6 \%$ in the younger stands, respectively. An inverse trend was observed for the most abundant pioneer species, namely, Pinus banksiana (see Figure 3). The observed decrease in the proportion of pioneer species over time may be related to canopy succession from postfire pioneer species towards dominance of $P$. mariana and, to a lesser extent, $A$. balsamea.

It has been suggested that postfire species composition and dynamics may differ among soil types [11-13]. In our study, we also noted that stand composition was associated with soil texture and also with temperature and precipitation regimes. In the two younger age class stands, the proportion of $P$. mariana was greater on finetextured than on coarse-textured soils (see Figure 3), while $P$. banksiana was particularly favored on coarse-textured soils receiving less precipitation. Seedbed type is an important factor affecting seed germination and seedling development. Germination and survival of $P$. banksiana is generally favored by mineral seedbeds and hindered by organic ones, while the opposite is observed for P. mariana [28, 29]. Among P. mariana companion species, A. balsamea was more abundant on colder sites or sites receiving higher amounts of precipitation, while $B$. papyrifera was more abundant on coarse-textured sites receiving higher precipitation (see Figure 3). Germination and early survival of B. papyrifera are often best on mineral soils; however, the small seeds of this species are also sensitive to soil moisture [30]. It has been demonstrated that excessively drained soils, insufficient rainfall, and unshaded and undisturbed seedbeds deterred its establishment [30]. Meanwhile, A. balsamea has the ability to be reproduced by layering in swamps and mossy areas [31]. Our findings regarding tree species composition in the northern boreal forest are in accordance with the reproductive ecology of these species.

4.2. Stand Structure. Both stand structure and structural changes over time were related to temperature and precipitation regimes. It is well known that air temperature controls the rate of plant metabolism, which in turn determines the amount of photosynthesis that can take place [32]. Temperature also influences forest soil and site productivity through the decomposition rate of organic matter [33]. The depth of the surface organic layer in $P$. mariana forests, which determines seedbed quality, is also influenced by fire frequency and severity, which are closely associated with the air temperature and precipitation regime [34]. On average, stand basal area, density, and height were positively related to the annual air temperature, while stand structural diversity was negatively related. Air temperature regime appears to have mainly influenced site stocking without, however, greatly influencing structural development trends over time. Stand density is mainly determined by regeneration conditions, including seed input and seedbed quality, soon after fire [35]. Also, the percentage of filled seeds and germination of $P$. mariana are associated with the regional variation in air temperature [35].

In opposition to the air temperature regime, site stocking capacity was not related to the precipitation regime, but structural development over time was. On sites receiving high amounts of precipitation, basal area and density increased from the first to the second age class, and then decreased for the 120-year age class, while basal area increased linearly with stand age on sites receiving low amounts; the maximum are reaching similar values for the 120-year age class in both precipitation classes (see Figure 4). It has been documented that when cohort stands are not destroyed by fire or other catastrophic disturbances, they continue to grow past peak maturity into a senescing or lowered vigour state $[36,37]$. From a combination of fire reconstruction maps and an ecological forest data base, Harper et al. [11] documented the stand-level structure along a postfire chronosequence at the landscape scale in the Abitibi region of Quebec, Canada. They observed that stand height and cover reached their maximum between 75-150 and 50-100 years following fire, respectively. Following this maximum, stand cover and height were reduced during the understory reinitiating phase, to reach a relative equilibrium state at the old-growth stage [12]. Furthermore, the rate of succession has been found to be greater on fine-textured soils, on soils showing higher nitrogen and moisture content, and in stands with higher productivity $[12,25,38]$. This greater dynamics may be explained by a higher growth rate for richer stands that likely induces earlier senescence [25]. Our results also revealed that the stand breakpoint, in terms of basal area and stand density, occurred sooner on sites receiving higher amounts of precipitation than on sites receiving less precipitation, without distinguishing between soil texture classes (see Figure 4).

4.3. Stand Dynamics. Stand dynamics analysis also revealed the influence of air temperature on the growth of living trees, and on stand mortality, recruitment, and net growth (see Figure 5). Overall, growth conditions appeared to be favored by a warmer temperature regime. The positive effect of air temperature regime on tree growth appears to be translated into a more abrupt senescing phase at a time when the pioneer cohort reaches maturity earlier on warmer sites than on colder ones. Over the last 30 years, negative net growth was clearly observed in older stands 

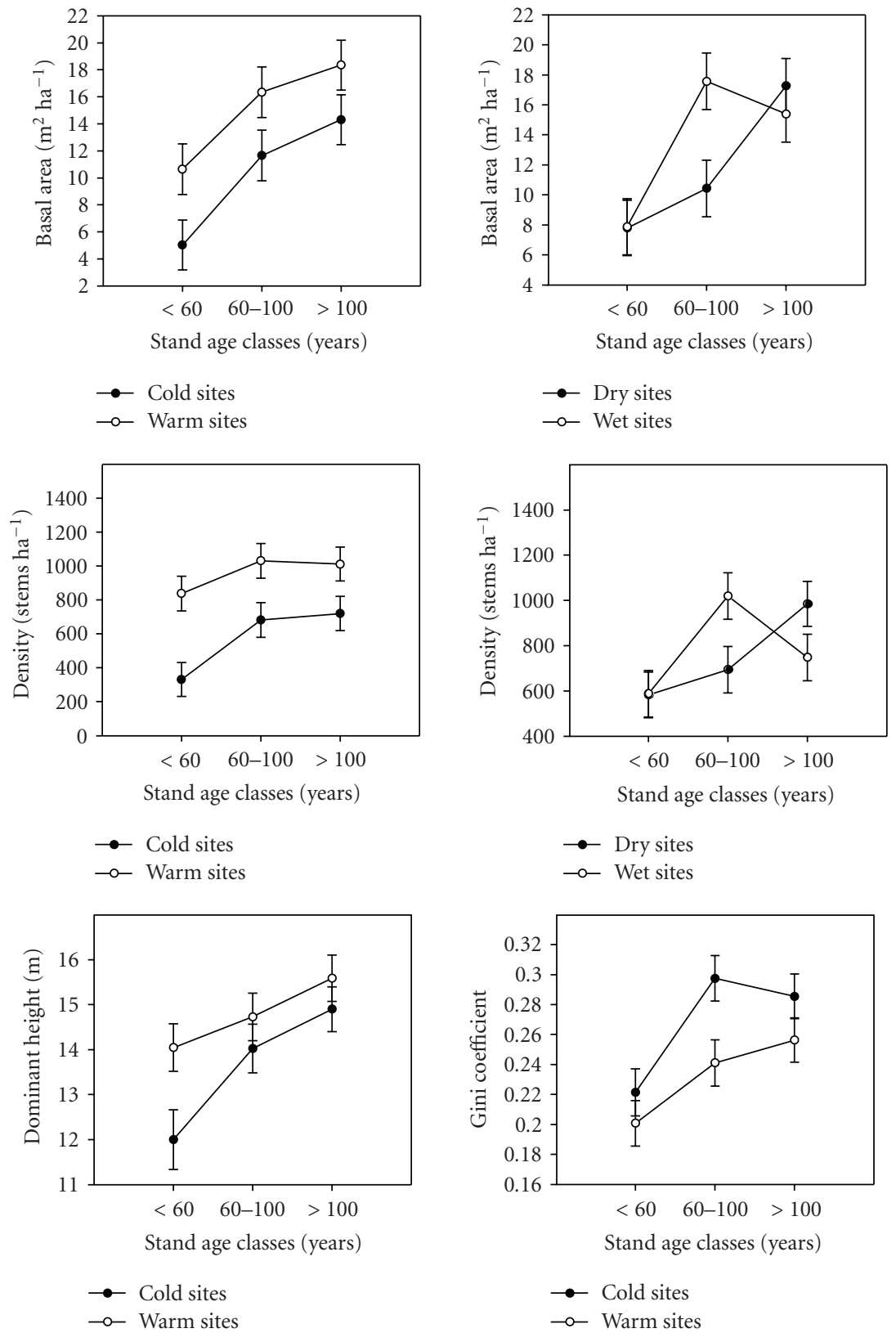

FIGURE 4: Relationships between stand structure and stand age, air temperature, precipitation, and soil texture. Data from the first inventory (1970-1975).

on sites in the warmer air temperature class. Contrary to results from the analysis of stand structure and composition (see Figure 4), and in agreement with Harper et al. [12], the analysis of the remeasured permanent plots revealed a significant relationship between soil texture and the timing of senescence (see Figure 5), apparently more rapid on finetextured than on coarse-textured soils.

4.4. Change in Stand Dynamics over Time. It has been reported that the shift in composition related to stand dynamics occurs generally sooner on more fertile sites because of faster growth and subsequent mortality of pioneer species [38]. Consequently, the duration of the transition phase is reduced on such sites. Improved tree growth over time may have reduced the stand transition period as compared to historical dynamics. The analysis of initial stand characteristics revealed that stand basal area increased with stand age, and rapidly reached a plateau, but on average, no decline in basal area was observed for the 120year-old stands (see Figure 4). These observations suggest that most of these stands had not yet peaked at this age class in terms of basal area. However, the contemporary dynamics observed from remeasurement data revealed a different portrait. Negative net growth was observed for the oldest age class (see Figure 5). In the meantime, the 

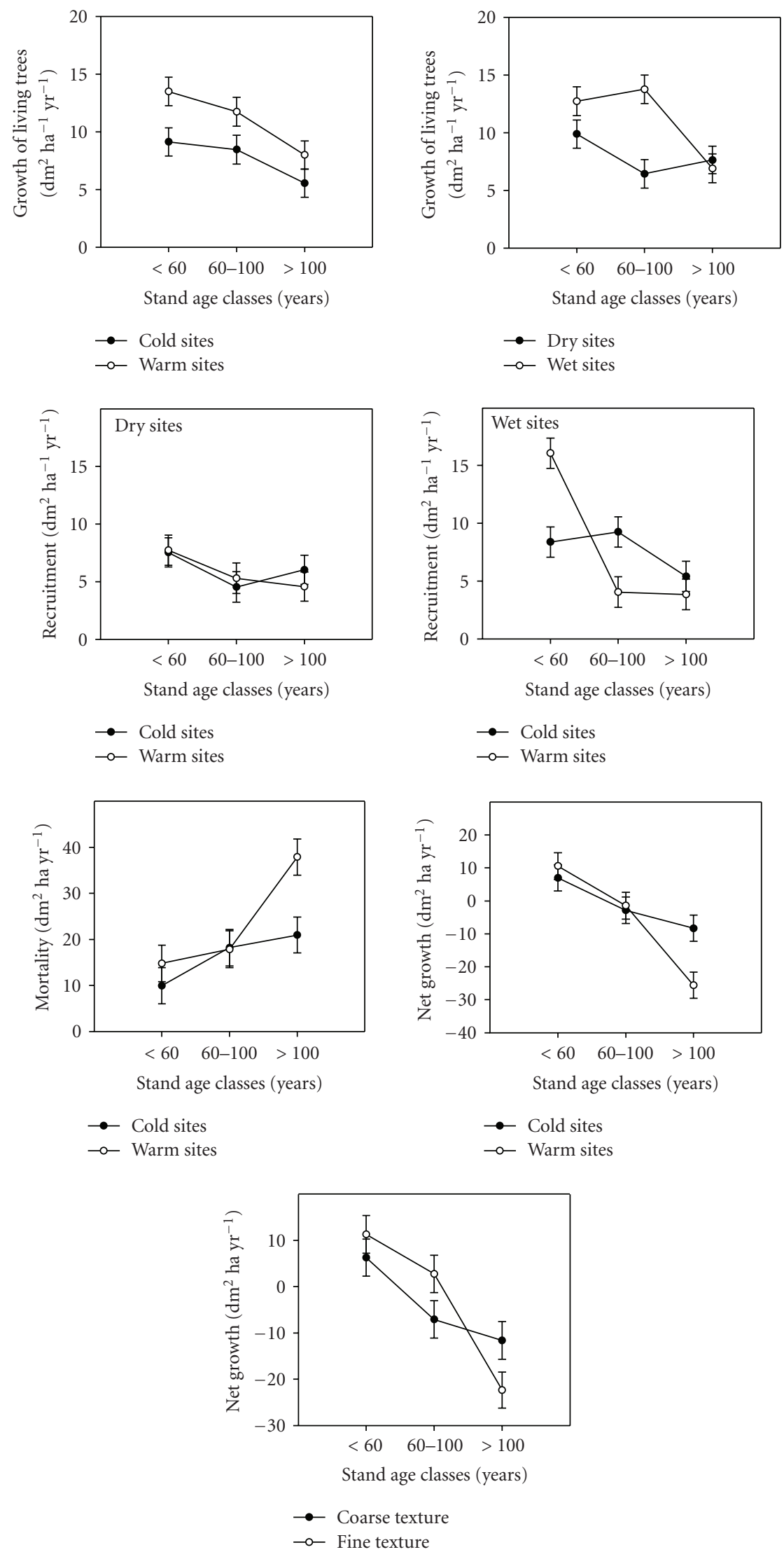

FIGURE 5: Relationships between parameters reflecting contemporary dynamics and stand age, air temperature, precipitation, and soil texture. Data from the two measurement periods (1970-1975 to 1978-1980 and 1990-1992 to 1998-2001). 

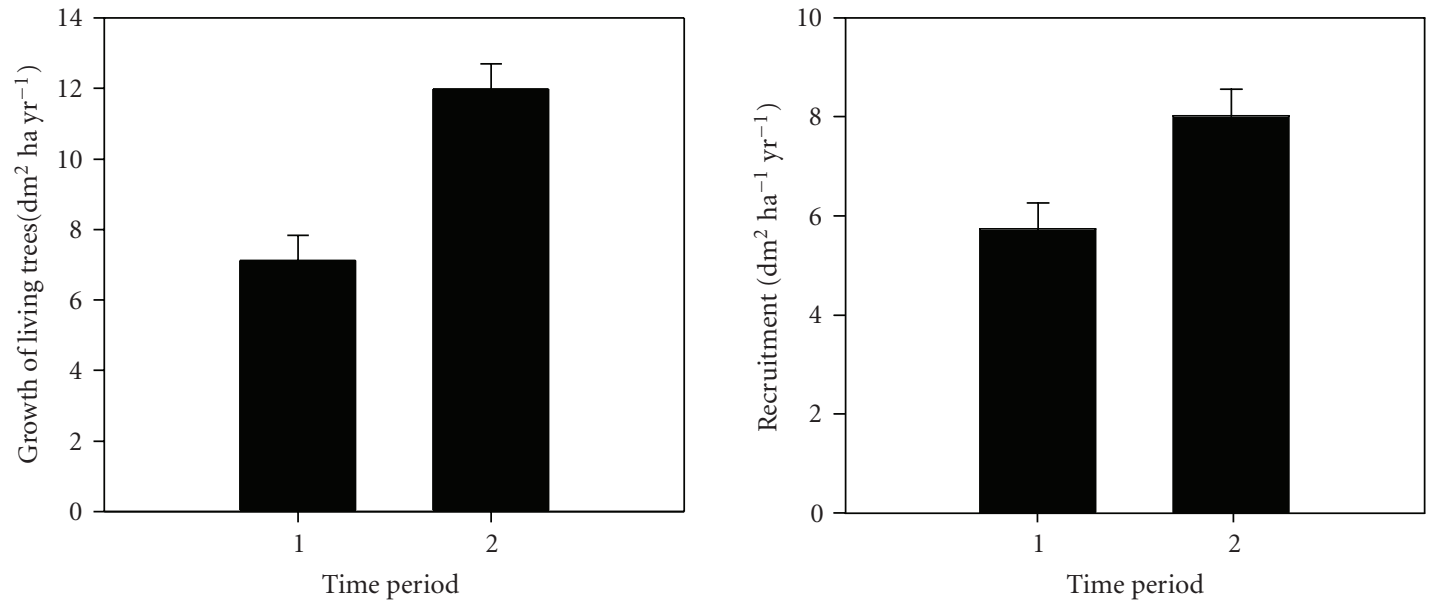

Time period
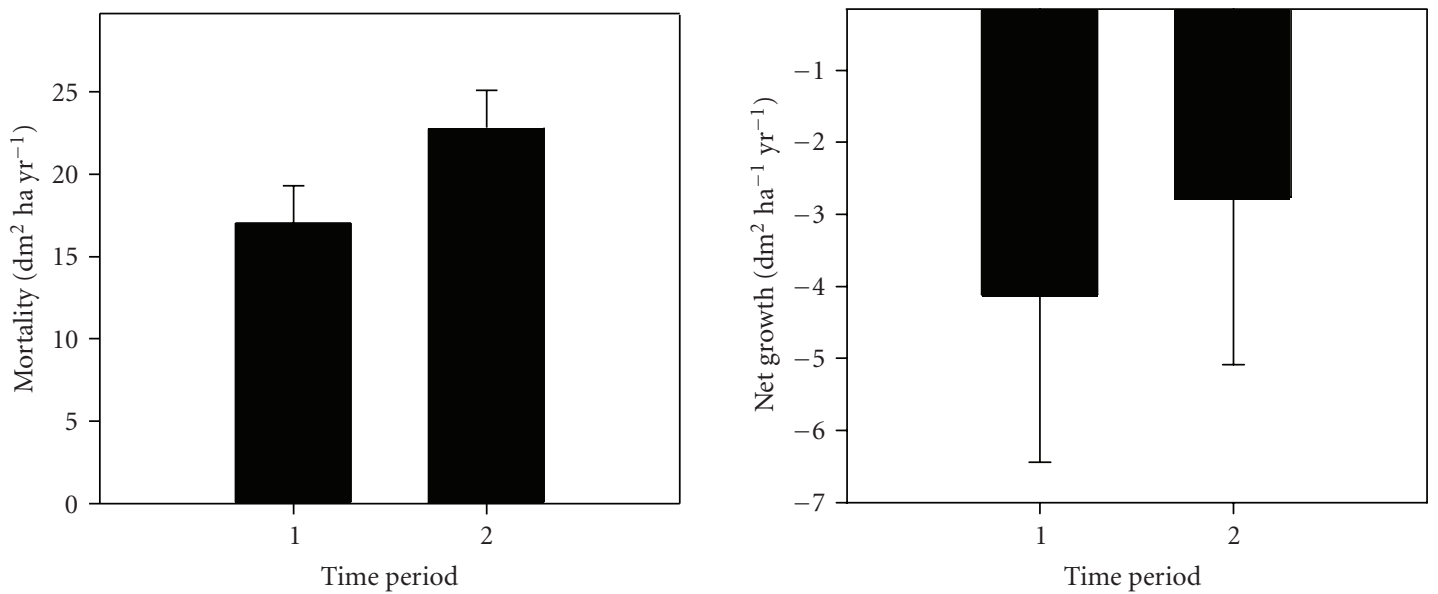

FIGURE 6: Tree growth and stand recruitment, mortality and net growth during two time periods: (1) 1970-1975 to 1978-1980 and (2) 1990-1992 to $1998-2001$.

TABle 2: Comparison of seasonal temperature, precipitation, and cumulative degree days during the two periods studied. Note: n.e. $=$ not estimated.

\begin{tabular}{|c|c|c|c|c|}
\hline Parameters & Time period 1 & Time period 2 & Change (\%) & $P$-value \\
\hline \multicolumn{5}{|c|}{ Temperature $\left({ }^{\circ} \mathrm{C}\right)$} \\
\hline Winter & $-17.5 \pm 0.09$ & $-17.8 \pm 0.11$ & -1.7 & $P=.077$ \\
\hline Spring & $4.9 \pm 0.07$ & $5.2 \pm 0.08$ & 5.9 & $P=.052$ \\
\hline Summer & $11.5 \pm 0.07$ & $12.1 \pm 0.07$ & 5.3 & $P \leq .001$ \\
\hline Autumn & $-8.3 \pm 0.11$ & $-7.0 \pm 0.10$ & 15.6 & $P \leq .001$ \\
\hline \multicolumn{5}{|c|}{ Total precipitation (mm) } \\
\hline Winter & $162 \pm 2.1$ & $144 \pm 1.3$ & -11.1 & $P \leq .001$ \\
\hline Spring & $254 \pm 2.3$ & $223 \pm 2.3$ & -12.2 & $P \leq .001$ \\
\hline Summer & $334 \pm 3.1$ & $366 \pm 2.2$ & 9.5 & $P \leq .001$ \\
\hline Autumn & $212 \pm 2.2$ & $219 \pm 1.8$ & 3.2 & $P=.018$ \\
\hline \multicolumn{5}{|c|}{ Snow precipitation $(\mathrm{mm})$} \\
\hline Winter & $150 \pm 2.1$ & $129 \pm 1.2$ & -14.2 & $P \leq .001$ \\
\hline Spring & $35 \pm 0.7$ & $26 \pm 0.4$ & -26.3 & $P \leq .001$ \\
\hline Summer & n.e. & n.e. & n.e. & n.e. \\
\hline Autumn & $118 \pm 2.1$ & $104 \pm 1.0$ & -11.9 & $P \leq .001$ \\
\hline
\end{tabular}


growth of living trees and stand recruitment increased by $68 \%$ and $40 \%$, respectively, from the first to the second period studied, independent of stand age, soil texture, air temperature, or precipitation regime (see Figure 6). These observations suggest that the shift in composition and the transition phase occurring in boreal forest ecosystems has accelerated under new environmental conditions in the last 30 years, as compared to the dynamics of the boreal forest in the last 100 years.

Generally, variation in tree growth and recruitment over time can be a result of changes in the intensity or frequency of partial perturbations such as insect defoliation, partial windfall, or partial burn. In the boreal coniferous forests of Canada, defoliation caused by spruce budworm (Choristoneura fumiferana [Clem.]) outbreaks has been one of the major natural disturbances leading to important tree mortality in balsam fir and spruce stands [39]. During the last spruce budworm outbreak (1975-1985) in Southern Quebec, tree growth and recruitment in balsam fir and black spruce stands were $23 \%$ and $51 \%$ lower, respectively, and mortality was 2.6 times higher than in the postoutbreak period [19]. Following the outbreak, mortality decreased and tree growth and recruitment increased. However, the present analyses do not indicate similar trends, because tree growth, recruitment, and mortality increased in synchronicity during the second period as compared to the first one. Differences between periods were greater for tree growth and recruitment than for mortality, while perturbations by insect outbreaks should affect primarily tree mortality, which is followed by an increase in growth of remnant trees and in recruitment. Moreover, among the plots studied, there was only one record of this perturbation in the survey plots. Partial windfall and partial burn were also rarely observed in the survey plots. Consequently, perturbation regimes do not appear to explain the observed trends over time.

In the present study, growth of living trees was 39\% higher in the warmer site class (mean temperature $-1.3^{\circ} \mathrm{C}$ ) as compared to the colder site class (mean temperature $-2.7^{\circ} \mathrm{C}$ ). Growth of living trees was also $40 \%$ higher on sites receiving higher precipitation (mean precipitation $984 \mathrm{~mm}$ ) as compared to drier sites (mean precipitation $883 \mathrm{~mm}$ ). Air temperature was considerably higher during the second period (mean temperature $-1.9^{\circ} \mathrm{C}$ ) as compared to the first one (mean temperature $-2.4^{\circ} \mathrm{C}$ ) (see Table 2). Summer precipitation and autumn precipitation (total precipitation $585 \mathrm{~mm}$ ) were also higher during the second period than in the first one (total precipitation $546 \mathrm{~mm}$ ). Since there were differences in growth among temperature and precipitation classes, differences in climatic conditions among the two time periods considered may explain the improved tree growth over time. At northern latitudes of the boreal forest in Quebec, it has been suggested that stem height growth has increased in response to the recent climate warming [40-43]. Snow precipitation was also lower in the second period as compared to the first period studied. At alpine timberline, it has been suggested that wind-driven snow and ice particles at the snow-air interface cause needle loss and the death of branches [44, 45], while cuticle erosion leads to desiccation or even needle loss and death
$[46,47]$. Such mechanisms may also play a role in the trend observed in the continuous forests studied herein. These observations suggest that climatic conditions were more favorable in the second study period than in the first one, and that climate was probably one of the main drivers for the improvement in tree growth from the first to the second period. Consequently, comparison of the results from the initial stand structure, the contemporary dynamics (growth, recruitment, and mortality), and the two periods considered suggests that changes in climatic conditions contributed to accelerate the successional dynamics of these ecosystems through their favorable effect on tree growth.

A direct effect of climate change on longevity of pioneer species is essential to drive the accelerated successional response herein proposed. For many species, tree longevity is positively correlated to wood density and negatively correlated with growth rates [48]. For example, pioneer species exhibit rapid growth and short longevity, while subcanopy species have slow growth and high longevity. Although mechanisms behind those relations are not fully understood, it has been suggested that slow growth of the trees results in a much greater mechanical strength in the wood that minimizes maintenance and repair costs while maximizing durability and strength [49].

\section{Conclusion}

Results of this study show that tree species composition of stands is associated with stand age, soil texture, air temperature, and precipitation regime. After establishment of the pioneer cohort, temperature and precipitation were associated with the postsuccessional dynamics probably by their influence on tree growth. Our results support the hypothesis that shifts in composition related to stand dynamics, and the subsequent senescing phase, generally occur sooner and more quickly on more fertile sites due to faster growth and the subsequent earlier mortality of pioneer species. This study suggests that climate warming will accelerate the successional dynamics of these ecosystems through its positive influence on tree growth.

\section{Acknowledgments}

This study is part of research project no. 112310069 of the Ministère des Ressources Naturelles et de la Faune du Québec (MRNFQ). The authors would like to thank Dr. Robert Jobidon for his helpful comments on an earlier version of this manuscript, Jean Noël for assistance in spatial data processing, Marie-Claude Lambert who generated meteorological data with the BioSim software, and two anonymous reviewers for helpful comments on the manuscript. They would also like to thank the staff of the Direction des Inventaires forestiers of the MRNFQ, who managed the permanent plot inventory program and supervised all field contractors who carried out the forest plot measurements over the years. 


\section{References}

[1] P. J. Burton, C. Messier, G. F. Weetmann, E. E. Prepas, W. L. Adamowicz, and R. Tittler, "The current state of boreal forestry and the drive for change," in Towards Sustainable Management of the Boreal Forest, P. J. Burton, C. Messier, D. W. Smith, and W. L. Adamowicz, Eds., NRC no. 544463, pp. 1-40, NRC Research Press, Ottawa, Canada, 2003.

[2] J. P. Saucier, J. F. Bergeron, P. Grondin, and A. Robitaille, "Les régions écologiques du Québec méridional ( $3^{\mathrm{e}}$ version): un des éléments du système hiérarchique de classification écologique du territoire mis au point par le ministère des Ressources naturelles du Québec," Supplément de l'Aubelle, no. 124, 1998.

[3] H. C. Fritts, T. J. Blasing, B. P. Hayden, and J. E. Kutzbach, "Multivariate techniques for specifying tree-growth and climate relationships and for reconstructing anomalies in paleoclimate," Journal of Applied Meteorology, vol. 10, no. 5, pp. 845-864, 1971.

[4] C.-H. Ung, P. Y. Bernier, F. Raulier, R. A. Fournier, M.-C. Lambert, and J. Régnière, "Biophysical site indices for shade tolerant and intolerant boreal species," Forest Science, vol. 47, no. 1, pp. 83-95, 2001.

[5] R. Groven and M. Niklasson, "Anthropogenic impact on past and present fire regimes in a boreal forest landscape of southeastern Norway," Canadian Journal of Forest Research, vol. 35, no. 11, pp. 2719-2726, 2005.

[6] V. H. Dale, L. A. Joyce, S. McNulty, et al., "Climate change and forest disturbances," BioScience, vol. 51, no. 9, pp. 723-734, 2001.

[7] Y. Bergeron, S. Gauthier, M. Flannigan, and V. Kafka, "Fire regimes at the transition between mixedwood and coniferous boreal forest in northwestern Quebec," Ecology, vol. 85, no. 7, pp. 1916-1932, 2004.

[8] Y. Bergeron, "Species and stand dynamics in the mixed woods of Quebec's southern boreal forest," Ecology, vol. 81, no. 6, pp. 1500-1516, 2000.

[9] C. V. Cogbill, "Dynamics of the boreal forests of the Laurentian Highlands, Canada," Canadian Journal of Forest Research, vol. 15, no. 1, pp. 252-261, 1985.

[10] L. De Grandpré, J. Morissette, and S. Gauthier, "Long-term post-fire changes in the northeastern boreal forest of Quebec," Journal of Vegetation Science, vol. 11, no. 6, pp. 791-800, 2000.

[11] K. A. Harper, Y. Bergeron, S. Gauthier, and P. Drapeau, "Postfire development of canopy structure and composition in black spruce forests of Abitibi, Québec: a landscape scale study," Silva Fennica, vol. 36, no. 1, pp. 249-263, 2002.

[12] K. Harper, C. Boudreault, L. DeGrandpré, P. Drapeau, S. Gauthier, and Y. Bergeron, "Structure, composition, and diversity of old-growth black spruce boreal forest of the Clay Belt region in Quebec and Ontario," Environmental Reviews, vol. 11, supplement 1, pp. S79-S98, 2003.

[13] N. Lecomte and Y. Bergeron, "Successional pathways on different surficial deposits in the coniferous boreal forest of the Quebec Clay Belt," Canadian Journal of Forest Research, vol. 35, no. 8, pp. 1984-1995, 2005.

[14] A. J. Hansen, R. P. Neilson, V. H. Dale, et al., "Global change in forests: responses of species, communities, and biomes," BioScience, vol. 51, no. 9, pp. 765-779, 2001.

[15] Environment Canada, Canadian Daily Climate Data: Temperature and Precipitation, Environment Canada, Downsview, Canada, 1996.

[16] Y. Bergeron, S. Gauthier, V. Kafka, P. Lefort, and D. Lesieur, "Natural fire frequency for the eastern Canadian boreal forest: consequences for sustainable forestry," Canadian Journal of Forest Research, vol. 31, no. 3, pp. 384-391, 2001.

[17] G. J. Bouyoucos, "Hydrometer method improved for making particle size analyses of soils," Agronomy Journal, vol. 54, no. 5, pp. 464-465, 1962.

[18] J. Régnière, "Generalized approach to landscape-wide seasonal forecasting with temperature-driven simulation models," Environmental Entomology, vol. 25, no. 5, pp. 869-881, 1996.

[19] L. Duchesne and R. Ouimet, "Population dynamics of tree species in southern Quebec, Canada: 1970-2005," Forest Ecology and Management, vol. 255, no. 7, pp. 3001-3012, 2008.

[20] N. L. Lexerød and T. Eid, "An evaluation of different diameter diversity indices based on criteria related to forest management planning," Forest Ecology and Management, vol. 222, no. 1-3, pp. 17-28, 2006.

[21] H. Sverdrup and P. Warfvinge, "Calculating field weathering rates using a mechanistic geochemical model PROFILE," Applied Geochemistry, vol. 8, no. 3, pp. 273-283, 1993.

[22] L. W. Petersen, P. Moldrup, O. H. Jacobsen, and D. E. Rolston, "Relations between specific surface area and soil physical and chemical properties," Soil Science, vol. 161, no. 1, pp. 9-21, 1996.

[23] SAS Institute, SAS version 9. SAS Institute, Cary, NC, USA, 2002.

[24] D. S. Robson, "A simple method for construction of orthogonal polynomials when the independent variable is unequally spaced," Biometrics, vol. 15, no. 2, pp. 187-191, 1959.

[25] D. Boucher, S. Gauthier, and L. De Grandpré, "Structural changes in coniferous stands along a chronosequence and a productivity gradient in the northeastern boreal forest of Québec," Ecoscience, vol. 13, no. 2, pp. 172-180, 2006.

[26] F. Wilcoxon, "Individual comparisons by ranking methods," Biometrics, vol. 1, no. 6, pp. 80-83, 1945.

[27] D. D. Kneeshaw and Y. Bergeron, "Canopy gap characteristics and tree replacement in the southeastern boreal forest," Ecology, vol. 79, no. 3, pp. 783-794, 1998.

[28] Z. Chrosciewicz, "Evaluation of fire-produced seedbeds for jack pine regeneration in central Ontario," Canadian Journal of Forest Research, vol. 4, no. 4, pp. 455-457, 1974.

[29] M. Lavoie, D. Paré, and Y. Bergeron, "Relationships between microsite type and the growth and nutrition of young black spruce on post-disturbed lowland black spruce sites in eastern Canada," Canadian Journal of Forest Research, vol. 37, no. 1, pp. 62-73, 2007.

[30] D. A. Perala and A. A. Alm, "Reproductive ecology of birch: a review," Forest Ecology and Management, vol. 32, no. 1, pp. $1-38,1990$.

[31] C. Krause, "Growth development of a balsam fir (Abies balsamea (L.) Mill.) originating from layering," Dendrochronologia, vol. 23, no. 3, pp. 139-143, 2006.

[32] C. Boisvenue and S. W. Running, "Impacts of climate change on natural forest productivity-evidence since the middle of the 20th century," Global Change Biology, vol. 12, no. 5, pp. 862-882, 2006.

[33] T. R. Moore, J. A. Trofymow, B. Taylor, et al., "Litter decomposition rates in Canadian forests," Global Change Biology, vol. 5, no. 1, pp. 75-82, 1999.

[34] M. Lavoie, D. Paré, N. Fenton, A. Groot, and K. Taylor, "Paludification and management of forested peatlands in Canada: a literature review," Environmental Reviews, vol. 13, no. 2, pp. 21-50, 2005.

[35] L. Sirois, "Spatiotemporal variation in black spruce cone and seed crops along a boreal forest-tree line transect," Canadian Journal of Forest Research, vol. 30, no. 6, pp. 900-909, 2000. 
[36] H. Leibungdut, "Über die dynamic europäischer urwäldern," Allgemeine Forst Zeitschrift für Waldwirtschaft und Umweltvorsorge, vol. 24, pp. 686-690, 1978.

[37] D. Mueller-Dombois, "Natural dieback in forests," BioScience, vol. 37, no. 8, pp. 575-583, 1987.

[38] J. A. Donnegan and A. J. Rebertus, "Rates and mechanisms of subalpine forest succession along an environmental gradient," Ecology, vol. 80, no. 4, pp. 1370-1384, 1999.

[39] H. Morin, Y. Jardon, and R. Gagnon, "Effects of insect outbreaks on forest dynamics," in Plant Disturbance Ecology: The Process and the Response, E. A. Johnson and K. Miyanishi, Eds., chapter 17, pp. 555-564, Academic Press, New York, NY, USA, 2007.

[40] I. Gamache and S. Payette, "Height growth response of tree line black spruce to recent climate warming across the foresttundra of eastern Canada," Journal of Ecology, vol. 92, no. 5, pp. 835-845, 2004.

[41] I. Gamache and S. Payette, "Latitudinal response of subarctic tree lines to recent climate change in eastern Canada," Journal of Biogeography, vol. 32, no. 5, pp. 849-862, 2005.

[42] K. Lescop-Sinclair and S. Payette, "Recent advance of the arctic treeline along the eastern coast of Hudson Bay," Journal of Ecology, vol. 83, no. 6, pp. 929-936, 1995.

[43] S. Vallée and S. Payette, "Contrasted growth of black spruce (Picea mariana) forest trees at treeline associated with climate change over the last 400 years," Arctic, Antarctic, and Alpine Research, vol. 36, no. 4, pp. 400-406, 2004.

[44] C. Lavoie and S. Payette, "Black spruce growth forms as a record of a changing winter environment at treeline, Quebec, Canada," Arctic and Alpine Research, vol. 24, no. 1, pp. 40-49, 1992.

[45] P. A. Scott, R. I. C. Hansell, and D. C. F. Fayle, "Establishment of white spruce populations and responses to climatic change at the treeline, Churchill, Manitoba, Canada," Arctic and Alpine Research, vol. 19, no. 1, pp. 45-51, 1987.

[46] J. L. Hadley and W. K. Smith, "Wind effects on needles of timberline conifers: seasonal influence on mortality," Ecology, vol. 67 , no. 1, pp. 12-19, 1986.

[47] J. L. Hadley and W. K. Smith, "Wind erosion of leaf surface wax in alpine timberline conifers," Arctic and Alpine Research, vol. 21, no. 4, pp. 392-398, 1989.

[48] W. F. Laurance, H. E. M. Nascimento, S. G. Laurance, R. Condit, S. D'Angelo, and A. Andrade, "Inferred longevity of Amazonian rainforest trees based on a long-term demographic study," Forest Ecology and Management, vol. 190, no. 2-3, pp. 131-143, 2004.

[49] D. W. Larson, "The paradox of great longevity in a short-lived tree species," Experimental Gerontology, vol. 36, no. 4-6, pp. 651-673, 2001. 

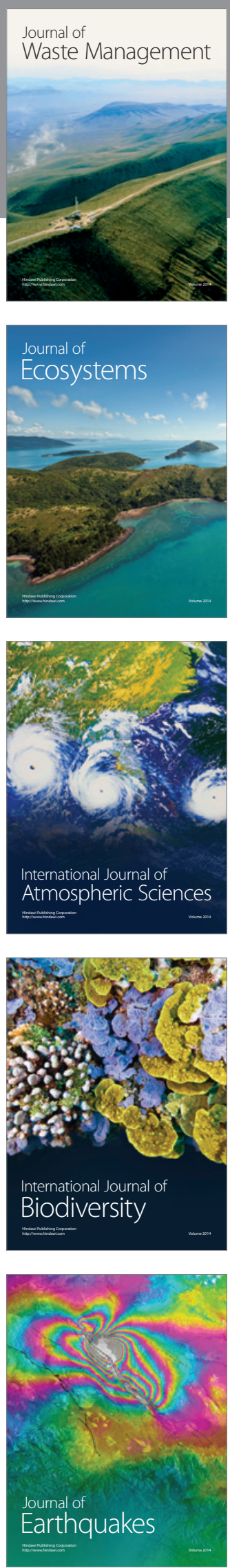
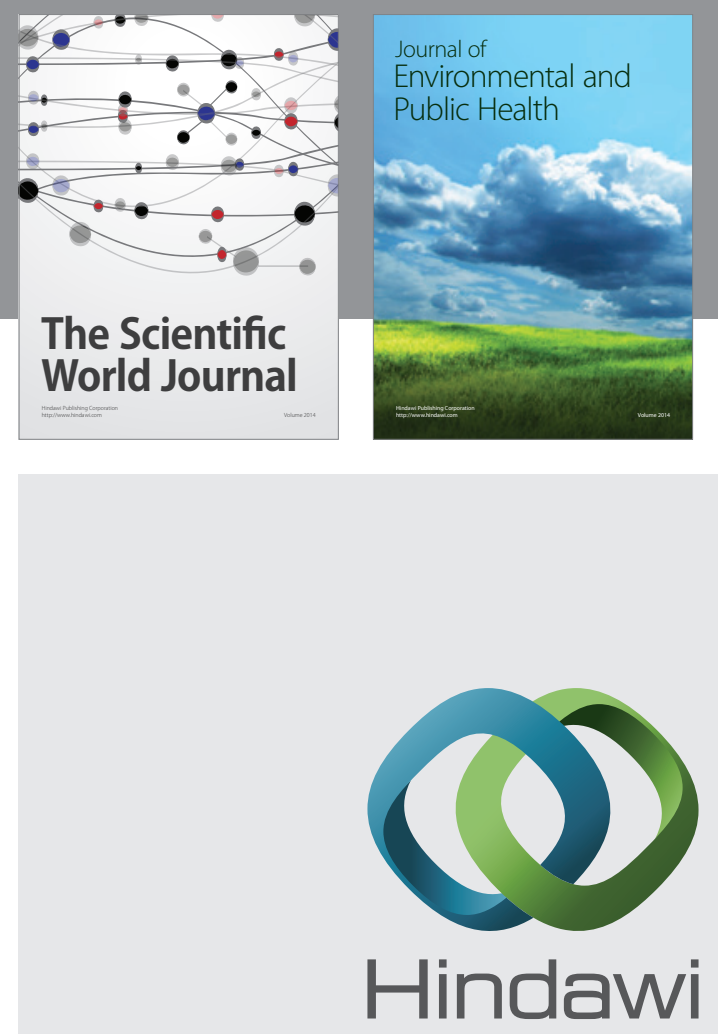

Submit your manuscripts at

http://www.hindawi.com
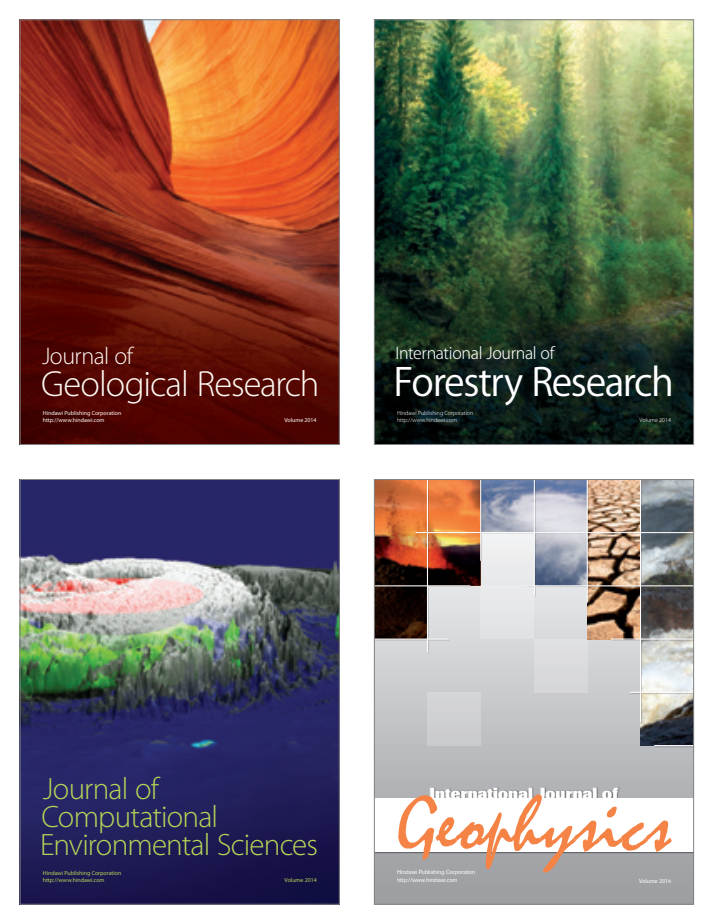
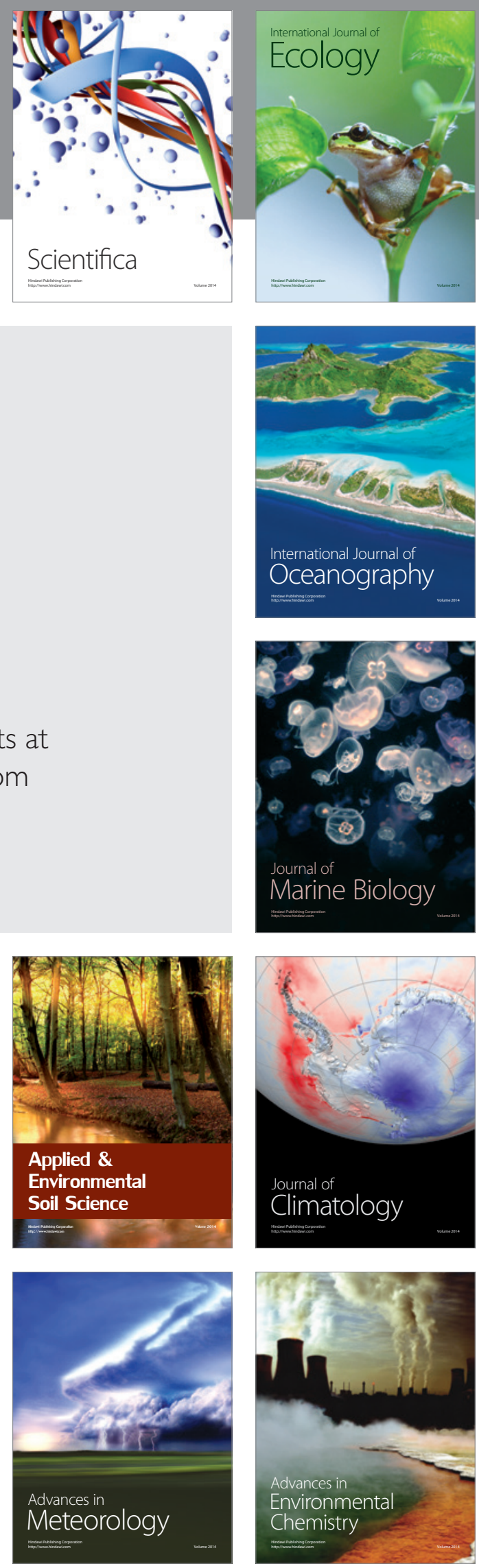